\title{
Determination of reference ranges for full blood count parameters in neonatal cord plasma in Hilla, Babil, Iraq
}

This article was published in the following Dove Press journal: Journal of Blood Medicine 28 September 2012

Number of times this article has been viewed

\author{
Jasim M Al-Marzoki' \\ Zainab W Al-Maaroof ${ }^{2}$ \\ Ali $\mathrm{H} \mathrm{Kadhum}^{3}$ \\ 'Department of Pediatrics, \\ ${ }^{2}$ Department of Pathology, Babylon \\ Medical College, ${ }^{3}$ Babylon Gynecology \\ and Pediatric Teaching Hospital, \\ Hilla, Iraq
}

Background: The health of an individual is known to vary in different countries, in the same country at different times, and in the same individuals at different ages. This means that the condition of individuals must be related to or compared with reference data. Determination of a reference range for the healthy term newborn is clinically important in terms of various complete blood count parameters. The purpose of this study was to establish a local reference range for full blood count parameters in neonatal cord plasma in Hilla, Babil, Iraq.

Methods: A total of 220 mothers and their neonates were enrolled in this cross-sectional study from February 2011 to January 2012. Maternal inclusion criteria were age 15-45 years, an uneventful pregnancy, and hemoglobin $\geq 10 \mathrm{~g}$. Neonatal inclusion criteria were full term (37-42 weeks) and normal birth weight. The umbilical cord was immediately clamped after delivery of the baby; $3 \mathrm{~mL}$ of cord blood was then taken from the umbilical vein and collected in a tube containing ethylenediamine tetra-acetic acid, its plasma was analyzed for full blood count parameters by standard Coulter gram, and the differential leukocyte count was done manually.

Results: Mean neonatal hemoglobin was $13.88 \pm 1.34$ (range 11-17.3) g/dL and mean white cell count was $10.12 \pm 2.8$ (range 3.1-21.6) $\times 10^{9} / \mathrm{L}$. Mean platelet count was $267.63 \pm 60.62$ (range $152-472) \times 10^{9} / \mathrm{L}$. No significant differences in red cell, white cell, or platelet counts were found between males and females, except for neutrophil count. The current study shows lower levels of hemoglobin, white cells, and red cells compared with other studies, and there is agreement with some studies and disagreement with others concerning platelet count.

Conclusion: Most results in the current study were within the reference range. The hematological reference values for Iraqi neonatal cord plasma need to be confirmed by larger numbers of blood samples and by collecting samples from different areas in Iraq.

Keywords: reference range, full blood count parameters, neonatal cord plasma

\section{Introduction}

The health of the individual is known to vary in different countries, in the same country at different times, and in the same individuals at different ages, meaning that the condition of the individual must be related to or compared with reference data. By comparing data for the individual collected during the medical interview, clinical examination, and supplementary investigations with the reference data, the condition of individuals can be interpreted. ${ }^{1}$ Investigation of an individual should depend on normal ranges established for the locality of that individual. ${ }^{2}$ The first study in neonatal hematology was published in 1924, when Lippman reported the morphologic and quantitative characteristics of blood corpuscles during the newborn period. ${ }^{3}$
Correspondence: Jasim M Al-Marzoki

Department of Pediatrics, Babylon

Medical College, Hilla, Iraq

Tel +96430244557;

+9647810204783 (mobile)

Email jalmarzoki@yahoo.com 
Since then, many hematologic studies have examined babies at different gestational ages and of varying birth weights. ${ }^{4}$ Furthermore, determination of a reference range for the healthy term neonate is clinically important in terms of a number of parameters in the complete blood count. For example, hemoglobin concentration is an important clinical measurement used in the clinical diagnosis, treatment, and public health interventions for anemia. ${ }^{5}$ Hemoglobin and hematocrit have been used routinely in the diagnosis of neonatal anemia and polycythemia. ${ }^{6}$ White blood cell and platelet counts have been proven to be helpful in the assessment of neonatal sepsis and the hemostatic status of the infant, respectively. ${ }^{7}$ Hematologic values are also frequently determined in the newborn for diagnostic purposes in cases of suspected infection and in those with bleeding disorders. ${ }^{8}$ The aim of this study was to establish a local reference range for full blood count parameters in neonatal cord plasma in Hilla, Babil, Iraq.

\section{Materials and methods}

A total of 220 mothers and their neonates were enrolled in this cross-sectional study conducted at the Babylon Gynecology and Children's Teaching Hospital from February 2011 to January 2012. Inclusion criteria for mothers were age 15-45 years, uneventful pregnancy, and hemoglobin $\geq 10 \mathrm{~g} / \mathrm{dL}$. Inclusion criteria for neonates were birth at full term (37-42 weeks) and normal birth weight $(2.5-4.0 \mathrm{~kg})$. Exclusion criteria for the mother were multiple pregnancy, eclampsia, diabetes mellitus, heart, kidney, or lung disease, hematologic disease, and emergency cesarean section. Exclusion criteria for neonates were perinatal blood loss, birth asphyxia, low Apgar score ( $<8$ at 5 minutes), and obvious congenital abnormality. Written informed consent was obtained from all the mothers.

\section{Blood sampling}

The umbilical cord was clamped immediately after delivery, and $3 \mathrm{~mL}$ of cord blood was taken from the umbilical vein and collected into a tube containing ethylenediamine tetra-acetic acid. The sample was then transported as soon as possible (maximum 3 hours) to the laboratory for analysis.

\section{Laboratory analysis}

For analysis of full blood count parameters, a standard Coulter gram was performed using a Diagon D-Cell 60 automated hematologic analyzer (Diagon Ltd, Budapest, Hungary). The differential leukocyte count and recording of nucleated red blood cells per 100 leukocytes was done manually by a specialist hematologist using a light microscope and Leishman's stained smears. If there was doubt about the results, a second opinion was sought from another specialist hematologist. All tests were undertaken by well trained competent laboratory staff.

\section{Statistical analysis}

The data were collected, organized, and tabulated using the Statistical Package for the Social Sciences version 19 software (SPSS Inc, Chicago, IL). The results are expressed in the form of numbers, ranges, and the mean \pm standard deviation. Differences between the means of variables regarding gender and comparisons with findings from other studies were performed using the $t$-test. A $P$ value $<0.05$ was considered to be statistically significant and $P<0.01$ to be highly significant.

\section{Results}

A total of 220 healthy full-term newborns (119 [54\%] males and 101 [46\%] females) were enrolled in this cross-sectional study conducted at the Babylon Gynecology and Children's Teaching Hospital from February 2011 to January 2012. Full blood count parameters from neonatal cord plasma are summarized in Table 1, which shows a mean hemoglobin level of $13.88 \pm 1.34$ (range 11-17.3) g/dL and a mean hematocrit of $44.42 \% \pm 4.74 \%$ (range $35.4 \%-56.5 \%$ ). The mean total white cell count was $10.12 \pm 2.8$ (range $3.1-$ $21.6) \times 10^{9} / \mathrm{L}$ and the mean platelet count was $267.63 \pm 60.62$ (range 152-472) $\times 10^{9} / \mathrm{L}$. Red blood cell parameters in cord plasma are summarized in Table 2 for males and females, and show no significant gender differences.

Table I Full blood count parameters in neonatal cord plasma

\begin{tabular}{|c|c|c|}
\hline Parameter & Range & Mean \pm SD \\
\hline Hemoglobin (g/dL) & $11-17.3$ & $13.76 \pm 1.46$ \\
\hline Red cell count $\left(\times 10^{12} / \mathrm{L}\right)$ & $3.12-7.3$ & $4 \pm 0.47$ \\
\hline Hematocrit (\%) & $35.4-56.5$ & $44.42 \pm 4.74$ \\
\hline $\mathrm{MCV}(\mathrm{fl})$ & $90.4-128$ & $111.56 \pm 6.09$ \\
\hline $\mathrm{MCH}(\mathrm{Pg})$ & $26-41.1$ & $34.4 I \pm 2.36$ \\
\hline $\mathrm{MCHC}(\mathrm{g} / \mathrm{dL})$ & $25.8-33.6$ & $30.93 \pm 1.90$ \\
\hline WBC $\left(\times 10^{9} / L\right)$ & $3.1-21.6$ & $10.12 \pm 2.8$ \\
\hline Lymphocytes (\%) & $15-75$ & $39.81 \pm 10.17$ \\
\hline Neutrophils (\%) & $15-78$ & $51 \pm 11.24$ \\
\hline Monocytes (\%) & $1-14$ & $7.85 \pm 2.77$ \\
\hline Basophils (\%) & $0-2$ & $0.10 \pm 0.36$ \\
\hline Eosinophils (\%) & $0-5$ & $1.22 \pm 0.97$ \\
\hline Nucleated RBC/I00 WBC & $0-3$ & $0.07 \pm 0.37$ \\
\hline Platelets count $\left(\times 10^{9} / \mathrm{L}\right)$ & $152-472$ & $267.63 \pm 60.62$ \\
\hline RDW & |l.4-2|.5 & $17.01 \pm 1.63$ \\
\hline
\end{tabular}

Abbreviations: WBC, white blood cells; $\mathrm{RBC}$, red blood cells; $\mathrm{MCH}$, mean corpuscular hemoglobin; RDW, red blood distribution width; MCHC, mean corpuscular hemoglobin concentration; MCV, mean cell volume; SD, standard deviation. 
Table 2 Gender distribution of red blood cell parameters in neonatal cord plasma

\begin{tabular}{|c|c|c|c|}
\hline Parameter & $\begin{array}{l}\text { Mean } \pm \text { SD } \\
(\text { male) } \\
119,54 \%\end{array}$ & $\begin{array}{l}\text { Mean } \pm \text { SD } \\
(\text { female) } \\
101,46 \%\end{array}$ & $P$ value \\
\hline Hemoglobin (g/dL) & $13.84 \pm 1.35$ & $13.68 \pm 1.58$ & 0.41 \\
\hline Red cell count $\left(\times 10^{12} / \mathrm{L}\right)$ & $3.98 \pm 0.39$ & $4.02 \pm 0.55$ & 0.53 \\
\hline Hematocrit (\%) & $44.48 \pm 4.67$ & $44.34 \pm 4.83$ & 0.82 \\
\hline $\operatorname{MCV}(\mathrm{fl})$ & $111.87 \pm 6.30$ & $111.20 \pm 5.85$ & 0.41 \\
\hline $\mathrm{MCH}(\mathrm{Pg})$ & $34.60 \pm 2.43$ & $34.19 \pm 2.27$ & 0.2 \\
\hline $\mathrm{MCHC}(\mathrm{g} / \mathrm{dL})$ & $30.95 \pm 1.17$ & $30.9 \pm 1.21$ & 0.7 \\
\hline Nucleated RBC/I00 WBC & $0.10 \pm 0.46$ & $0.03 \pm 0.24$ & 0.16 \\
\hline
\end{tabular}

Abbreviations: WBC, white blood cells; RBC, red blood cells; $\mathrm{MCH}$, mean corpuscular hemoglobin; MCHC, mean corpuscular hemoglobin concentration; $\mathrm{MCV}$, mean cell volume; SD, standard deviation.

The hemoglobin concentration was $13.84 \pm 1.35 \mathrm{~g} / \mathrm{dL}$ in males and $13.68 \pm 1.58 \mathrm{~g} / \mathrm{dL}$ in females $(P=0.41)$, and mean cell volume $(\mathrm{MCV})$ was $111.87 \pm 6.30 \mathrm{fl}$ in males compared with $111.20 \pm 5.85 \mathrm{fl}$ in females $(P=0.41)$. The platelet count and white blood cell parameters in cord plasma for males and females are summarized in Table 3, which shows no significant difference in parameters between the genders apart from the percentage of neutrophils. Total white cell count was $10.19 \pm 3.01 \times 10^{9} / \mathrm{L}$ in males compared with $10.03 \pm 2.55 \times 10^{9} / \mathrm{L}$ in females $(P=0.6)$, mean neutrophil percentage was $49.30 \% \pm 11.97 \%$ in males and $52.98 \% \pm 10.44 \%$ in females $(P=0.01)$, and mean platelet count was $268.35 \pm 59.38 \times 10^{9} / \mathrm{L}$ in males and $266.80 \pm 62.30 \times 10^{9} / \mathrm{L}$ in females $(P=0.8)$.

Table 4 compares red blood cell parameters in neonatal cord plasma from the current study with reference values ${ }^{9}$ and those of other studies that have used neonatal cord blood. The results were within reference values. Hemoglobin levels in the current study were lower than those in studies from Karachi, $\operatorname{Pakistan}^{10}(14.99 \pm 1.47 \mathrm{~g} / \mathrm{dL})$, Al-nahrain, Baghdad, Iraq ${ }^{11}$

Table 3 Gender distribution of white blood cell and platelet counts in neonatal cord plasma

\begin{tabular}{lccl}
\hline Parameter & $\begin{array}{l}\text { Mean } \pm \text { SD } \\
\text { (male) } \\
\text { I 19, 54\% }\end{array}$ & $\begin{array}{l}\text { Mean } \pm \text { SD } \\
\text { (female) } \\
\text { I01, 46\% }\end{array}$ & P value \\
\hline $\begin{array}{l}\text { Total WBC count } \\
\left(\times 10^{9} / \mathrm{L}\right)\end{array}$ & $10.19 \pm 3.01$ & $10.03 \pm 2.55$ & 0.6 \\
Lymphocytes (\%) & $41.05 \pm 10.60$ & $38.39 \pm 9.5 \mathrm{I}$ & 0.053 \\
Neutrophils (\%) & $49.30 \pm 11.97$ & $52.98 \pm 10.44$ & 0.01 \\
Monocytes (\%) & $8.05 \pm 2.7 \mathrm{I}$ & $7.62 \pm 2.83$ & 0.2 \\
Basophils (\%) & $0.11 \pm 0.36$ & $0.10 \pm 0.36$ & 0.8 \\
Eosinophils (\%) & $1.13 \pm 1.01$ & $1.10 \pm 0.93$ & 0.8 \\
Platelet count $\left(\times 10^{9} / \mathrm{L}\right)$ & $268.35 \pm 59.38$ & $266.8 \pm 62.30$ & 0.8 \\
\hline
\end{tabular}

Abbreviations: SD, standard deviation; WBC, white blood cells.

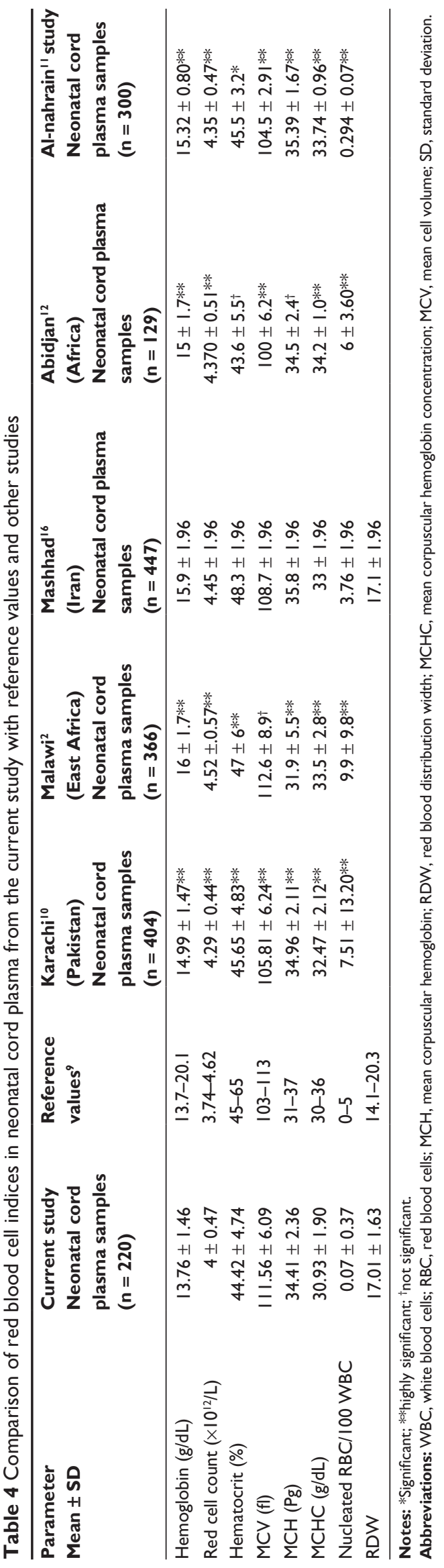


$(15.32 \pm 0.80 \mathrm{~g} / \mathrm{dL})$ and Malawi ${ }^{2}(16 \pm 1.7 \mathrm{~g} / \mathrm{dL})$. Hematocrit levels in the current study are in agreement with those in Abidjan, Africa ${ }^{12}(43.6 \% \pm 5.5 \%)$ but were lower than in the $\operatorname{Karachi}^{10}(45.65 \% \pm 4.83 \%)$, Malawi ${ }^{2}(47 \% \pm 6 \%)$ and Al-nahrain ${ }^{11}(45.5 \% \pm 3.2 \%)$ studies.

Table 5 compares platelet counts and white blood cell indices in neonatal cord plasma between the current study and other studies using neonatal cord blood, and the results were within reference values. The mean total white cell count in the current study was lower than that in the studies from Malawi ${ }^{2}$ $\left(12.3 \pm 4.8 \times 10^{9} / \mathrm{L}\right), \operatorname{Karachi}^{10}\left(13.61 \pm 4.23 \times 10^{9} / \mathrm{L}\right), \operatorname{Abidjan}^{12}$ $\left(13.7 \pm 5.4 \times 10^{9} / \mathrm{L}\right)$, and Al-nahrain ${ }^{11}\left(15.1 \pm 3.17 \times 10^{9} / \mathrm{L}\right)$. The mean platelet count in the current study was in agreement with those from Karachi ${ }^{10}\left(256.25 \pm 76.54 \times 10^{9} / \mathrm{L}\right)$ and Malawi $^{2}\left(259.9 \pm 72.55 \times 10^{9} / \mathrm{L}\right)$, but was higher than those from Al-nahrain ${ }^{11}\left(221.8 \pm 27.26 \times 10^{9} / \mathrm{L}\right)$ and Abidjan ${ }^{12}$ $\left(161 \pm 45 \times 10^{9} / \mathrm{L}\right)$.

\section{Discussion}

Reference values have a great impact on interpretation of test results, and there is always a need to compare results obtained with these values. ${ }^{13}$ We should not use the incorrect term of "normal range" because concepts of health and disease are discussed from the laboratory point of view, and reference values are not always derived from "healthy" people. To be more exact, it is better to use terms such as "reference values" or "reference ranges". ${ }^{14}$ Interpretation of values obtained for a given baby depends on knowledge of the normal values for the locality. ${ }^{15}$ Hence, a study was conducted at the Babylon Gynecology and Children's Teaching Hospital to define reference ranges for full blood count parameters in neonatal cord plasma. Most of these parameters were within reference values. In the current study, we did not find any polycythemia, probably because we selected term and normal for gestational age neonates, whereas polycythemia (hematocrit $>65 \%$ ) is relatively common in preterm and small for gestational age neonates. ${ }^{16}$

No significant gender differences in blood cell parameters and white blood cell indices were found for neonatal cord plasma, which is in agreement with the research by Mukiibi et al. ${ }^{17,18}$ The percentage of neutrophils was found to be significantly different between males and females $(P=0.01)$. Comparison of red blood cell parameters in neonatal cord plasma for the current study with reference values cited by other studies shows that hemoglobin and red cell counts were significantly lower than those reported for Malawi, ${ }^{2}$ Karachi, ${ }^{10} \mathrm{Al}$-nahrain, ${ }^{11}$ and Abidjan. ${ }^{12}$ Hematocrit values in the current study agree with those from Abidjan ${ }^{12}$ but

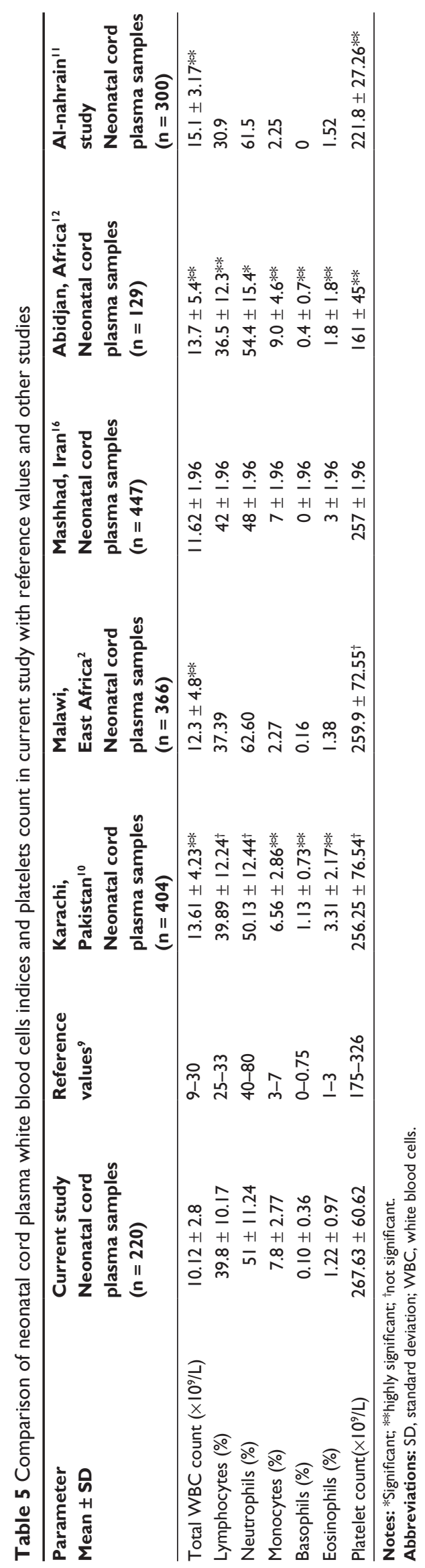


were significantly lower than those from Malawi, ${ }^{2}$ Karachi, ${ }^{10}$ and Al- nahrain. ${ }^{11}$ This may be due to varying numbers of newborns, time interval between birth and clamping of the cord, ethnic differences, severity of anemia in the mothers, or the mother not having received routine hematinics during pregnancy. ${ }^{17}$ Mean cell volume results were in agreement with those from Malawi ${ }^{2}$ but were higher than those from Karachi, ${ }^{10} \mathrm{Al}$-nahrain, ${ }^{11}$ and Abidjan. ${ }^{12}$ This may be related to race and geographic variations, especially altitude from sea level. ${ }^{19}$ Mean corpuscular hemoglobin values in the current study agree with the results of the Abidjan ${ }^{12}$ study but are higher than those for the Malawi ${ }^{2}$ study and lower than for the Karachi ${ }^{10}$ and Al-nahrain ${ }^{11}$ studies. This may be due to varying numbers of newborns, race, stress during pregnancy, maternal factors, low socioeconomic status, and geographic distribution. Mean corpuscular hemoglobin concentration results are significantly lower than those of other studies, ${ }^{2,10-12}$ which may be due to varying numbers of newborns, time interval between birth and clamping of the cord, ethnic differences, and severity of anemia in the mothers. Nucleated red blood cells are normally seen in the blood of neonates during the first week of life, ${ }^{19}$ indicating a degree of hypoxia during labor. However, nucleated red blood cell values in the current study were lower than in other studies, ${ }^{2,10-12}$ which might be attributed to a difference in mean gestational age because there was a significant inverse relationship between numbers of nucleated red blood cells and gestational age, ${ }^{20}$ or might be due to the number of samples taken. Red blood cell distribution width values in the current study were within the reference range; however, other studies used for comparison did not include this parameter.

The total white blood cell count in the current study was within the reference values but lower than in other studies. ${ }^{2,10-12}$ These differences might be attributable to differences in timing of collection of blood samples and/ or the site of blood sampling. ${ }^{21}$ Lymphocyte and neutrophil percentages in the current study agree with those from the Karachi ${ }^{10}$ study, but lymphocyte levels were higher and neutrophil levels were lower than for the Abidjan ${ }^{12}$ study, which may reflect the size of the sample and racial factors. The percentage of monocytes in the current study was higher than in the Karachi ${ }^{10}$ study but lower than in the Abidjan ${ }^{12}$ study, and the percentages of basophils and eosinophils in the current study were lower than those in the Karachi ${ }^{10}$ and Abidjan ${ }^{12}$ studies, which may be related to the size of the sample and racial factors. The platelet count in the current study is in agreement with that from the Malawi ${ }^{2}$ and Karachi ${ }^{10}$ studies, but is higher than that for the Al-nahrain ${ }^{11}$ and Abidjan ${ }^{12}$ studies, possibly because of environmental factors, such as the medicinal herbs widely used in Africa (eg, feverfew and gingko biloba, which are antiplatelet agents), contamination with Wharton jelly, poverty, and malnutrition. ${ }^{18}$

\section{Conclusion}

Most results in the current study were within reference ranges. There was no significant difference between males and females regarding full blood counts in neonatal cord plasma apart from the percentage of neutrophils. There is both agreement and disagreement between the current study and other studies inside and outside of Iraq. The hematologic reference values for Iraqi newborns need to be confirmed by larger numbers of blood samples and collecting samples from different areas of Iraq.

\section{Disclosure}

The authors report no conflicts of interest in this work.

\section{References}

1. Ashavaid TF, Todur SP, Dherai AJ. Establishment of reference intervals in Indian population. Indian J Clin Biochem. 2005;20:110-118.

2. Mukiibi JM, Mtimavalye LA, Broadhead R, et al. Some hematological parameters in Malawian neonates. East Afr Med J. 1995;72:10-14.

3. Lippman HS. Morphologic and quantitative study of blood corpuscles in neonatal period. Am J Dis Child. 1924;27:473-526.

4. Stancheva VP, Sherman GG, Avent M, et al. Hematological reference ranges in black very low birth weight infants. Pediatr Hematol Oncol. 2002;19:91-94.

5. McElory PD, Lal AA, Hawley WA, et al. Analysis of repeated hemoglobin measures in full term, normal birth weight Kenyan children between birth and four years of age. Am J Trop Med Hyg. 1999;61:932-940.

6. Mamoury GH, Hamedy AB, Alkhlaghi F. Cord hemoglobin in newborn in correlation with maternal hemoglobin in Northeastern Iran. Iran $J$ Med Sci. 2003;28:166-168.

7. Marwaha N, Marwaha RK, Narang A, Thusu K, Garewal G, Bhakoo ON Routine hematological values in term newborns. Indian Pediatr. 1992;29:1095-1099.

8. Abdurrahman MB, Adekoje MA. Hematological values in Northern Nigerian neonates. Trans R Soc Trop Med Hyg. 1983;77:786-788.

9. Nicholson JF, Pesce MA. Laboratory testing in infants and children. In: Behrman RE, editor. Nelson Textbook of Pediatrics. 19th ed. Philadelphia, PA: Saunders; 2011.

10. Qaiser DH, Sandila MP, Ahmed ST, Kazmi T. Haematological reference values for full term, healthy, newborns of Karachi, Pakistan. J Pak Med Assoc. 2009;59(9):618-622.

11. Salem Al-Mudallal S, Abd Al-Moeen Al-Habbobi M. Evaluation of the effect of mode of delivery on hematological parameters of healthy full-term newborns. Iraqi J Med Sci. 2010;8:30-32.

12. Reinhardt MC, Marti HR. Hematological data of African newborns and their mothers in Abidjan. Helv Paediatr Acta Suppl. 1978;41:85-99.

13. Jopling J, Henry E, Weidmeier SE. Reference ranges for hematocrit and blood hemoglobin concentration during the neonatal period: Data from a multi hospital healthcare system. Pediatrics. 2009;123:e333-e337.

14. Solberg HE. Establishment and use of reference. In:Burtis CA,AshwoodER, Bruns DE, editors. In: Tietz Textbook of Clinical Chemistry and Molecular Diagnostics. 4th ed. Philadelphia, PA: Elsevier Saunders; 2006. 
15. Keramati MR, Maybodi NT. The effect of iron deficiency anemia (IDA) on the $\mathrm{HbA} 2$ level and comparison of hematologic values between IDA and thalassemia minor. UHOD. 2007;17:151-156.

16. Keramati MR, Zadeh AM, Farhat AS, et al. Determination of hematologic reference values of neonates in Mashhad Iran. International Journal of Hematology and Oncology. 2011;21:103-104.

17. Mukiibi JM, Nkrumah FK, Kaur M, Pollard R, Akino V, Nhembe. Neonatal hematology in Zimbabwe-II. The red cell and white cell parameters. Cent Afr J Med. 1995;41:76-82.

18. Mukiibi JM, Nkrumah FK, Kaur M, Pollard R, Akino V, Nhembe M. Neonatal hematology in Zimbabwe-I. The platelet parameters. Cent Afr J Med. 1994;40:80-83.
19. Vajpayee N, Graham SS, Bem S. Basic examination of blood and bone marrow. In: McPherson RA, Pincus MR, editors. Henry's Clinical Diagnosis and Management by Laboratory Methods. 21st ed. Philadelphia, PA: Saunders Elsevier; 2007.

20. Hord JD, Lukens JN. Anemias unique to infants and young children. In: Lee GR, Forester J, Lulens J, et al, editors. Wintrobe's Clinical Hematology. 10th ed. Baltimore, MD: Williams and Willkins; 1998.

21. Xanthou M. Leukocyte blood picture in healthy full-term and premature babies during neonatal period. Arch Dis Child. 1970;45:242-249.

Journal of Blood Medicine

\section{Publish your work in this journal}

The Journal of Blood Medicine is an international, peer-reviewed, open access, online journal publishing laboratory, experimental and clinical aspects of all topics pertaining to blood based medicine including but not limited to: Transfusion Medicine; Blood collection, Donor issues, Transmittable diseases, and Blood banking logistics; Immunohematology; Artificial and alternative

\section{Dovepress}

blood based therapeutics; Hematology; Biotechnology/nanotechnology of blood related medicine; Legal aspects of blood medicine; Historical perspectives. The manuscript management system is completely online and includes a very quick and fair peer-review system. Visit http://www.dovepress.com/ testimonials.php to read real quotes from published authors. 